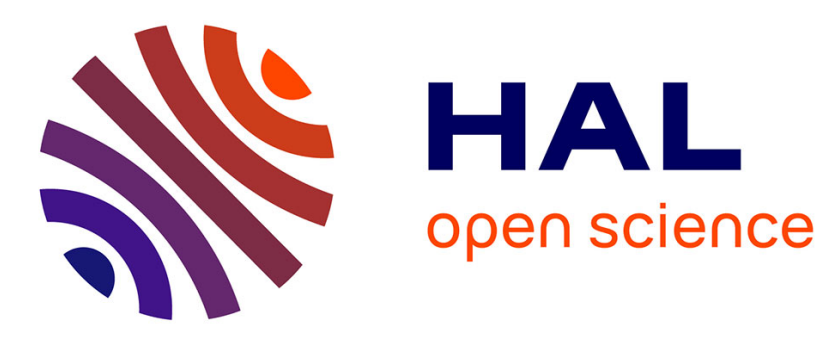

\title{
Effect of Additives on the Magnetic Properties in $\mathrm{Mg}-\mathrm{Cu}-\mathrm{Zn}$ Ferrite
}

\author{
J. Park, J. Kim, S. Cho
}

\section{To cite this version:}

J. Park, J. Kim, S. Cho. Effect of Additives on the Magnetic Properties in Mg-Cu-Zn Ferrite. Journal de Physique IV Proceedings, 1997, 07 (C1), pp.C1-193-C1-194. 10.1051/jp4:1997171 . jpa-00255118

\section{HAL Id: jpa-00255118 https://hal.science/jpa-00255118}

Submitted on 1 Jan 1997

HAL is a multi-disciplinary open access archive for the deposit and dissemination of scientific research documents, whether they are published or not. The documents may come from teaching and research institutions in France or abroad, or from public or private research centers.
L'archive ouverte pluridisciplinaire HAL, est destinée au dépôt et à la diffusion de documents scientifiques de niveau recherche, publiés ou non, émanant des établissements d'enseignement et de recherche français ou étrangers, des laboratoires publics ou privés. 


\title{
Effect of Additives on the Magnetic Properties in $\mathrm{Mg}-\mathrm{Cu}-\mathrm{Zn}$ Ferrite
}

\author{
J. Park, J. Kim* and S. Cho*
}

\author{
Division of Ferrite, Samsung Corning Co., Ltd., 644 Jinpyung-dong, Gumi-city Kyungpook 730-340, \\ Korea \\ * Department of Inorganic Materials Engineering, Kyungpook Univ., 1730 Sankyuk-dong, Puk-gu, Taegu \\ 702-701, Korea
}

\begin{abstract}
A bstract. The adding effect of $\mathrm{NiO}, \mathrm{CnO}_{3}$ on magnetic properties in $\mathrm{Mg}$ - $\mathrm{Cu}-\mathrm{Zn}$ ferrite was investigated. The samples were prepared with conventional ceramic process at the sintering temperature of $1080^{\circ} \mathrm{C}$. The two dopants were added in small quantities in steps of $0.3,0.6,0.9,12 \mathrm{wt} \%$, respectively. Microstructure and magnetic properties depending on temperature were investigated. The introduction of additives $\mathrm{NiO}, \mathrm{CrO}_{3}$ in $\mathrm{Mg}-\mathrm{Cu}-\mathrm{Zn}$ ferrite can successfully promote the temperature properties in lowering the relative temperature coefficient.

Key Words : $\mathrm{Mg}-\mathrm{Cu}-\mathrm{Zn}$ ferrite, initial permeability, relative temperature coefficient, curie temperature, saturation magnetization, magnetocrystalline anisotropy.
\end{abstract}

\section{Introduction}

Among the soft ferrites which were denoted $\mathrm{MO} \cdot \mathrm{Fe}_{2} \mathrm{O}_{3}(\mathrm{M}=\mathrm{Ni}, \mathrm{Zn}, \mathrm{Cu}, \mathrm{Mg}, \mathrm{Mn})$, $\mathrm{Ni}-\mathrm{Cu}-\mathrm{Zn}$ ferrite was widely used in electromagnetic parts material such as rotary transformer core, intermediate frequency transformer core, EMI core, deflection yoke core and so on.

However, among the raw materials in this composition, $\mathrm{NiO}$ is very expensive, therefore $\mathrm{MgO}$ is substituted for $\mathrm{NiO}$ for the purpose of cost reduction in industial field. Comparing with $\mathrm{Ni}-\mathrm{Cu}-\mathrm{Zn}$ ferrite, $\mathrm{Mg}$ $\mathrm{Cu}-\mathrm{Zn}$ ferrite have similar magnetic properties in some range but the initial permeability is very unstable according to temperature.

The temperature dependence of initial permeability has been studied in $\mathrm{Mn}-\mathrm{Zn}[1,2]$, or $\mathrm{Ni}-\mathrm{Zn}$ ferrite[3,4]but it is never to be found on $\mathrm{Mg}-\mathrm{Cu}-\mathrm{Zn}$ ferrite. The motivation to investigate the $\mathrm{Mg}-\mathrm{Cu}-\mathrm{Zn}$ ferrite is lying on their low cost and their applications. The aim of this work is to develope the advantages of $\mathrm{Mg}-\mathrm{Cu}-\mathrm{Zn}$ ferrite and to improve temperature stability.

\section{Experiment}

The basic ferrite has a molecular composition $(\mathrm{MgO})_{20.0}(\mathrm{CuO})_{7.0}(\mathrm{ZnO})_{24.0}\left(\mathrm{Fe}_{2} \mathrm{O}_{3}\right)_{49.0}$ to which 0.5 wt\% $\mathrm{Li}_{2} \mathrm{CO}_{3}$ and $0.03 w t \% \quad \mathrm{Bi}_{2} \mathrm{O}_{3}$ was added. The raw materials were mixed with attritor and dried in oven. After calcination at $900^{\circ} \mathrm{C}$ for $2 \mathrm{hrs}$, the two dopants $\left(\mathrm{NiO}, \mathrm{Cr}_{2} \mathrm{O}_{3}\right)$ were added in milling process with attritor in small quantities in steps of $0.0,0.3,0.6,0.9,1.2 \mathrm{wt} \%$, respectively. The samples were spray dried along with binders and lubricants. The powders were each pressed into toroidals of approximate dimensions, $\phi 30 \mathrm{~min}$ out diameter and $\phi 18 \mathrm{~mm}$ inner diameter at a pressing pressure of $1.0 \mathrm{ton} / \mathrm{cm}^{2}$. Sintering of these toroidals was done in an air atmosphere box furnace at the soaking temperature of $1080^{\circ} \mathrm{C}$ for $1 \mathrm{hr}$.

The initial permeability and $\tan \delta / \mu_{i}$ were measured at $1 \mathrm{MHz}$ with impedance analyzer(HP4194A) and temperature dependence of initial permeability was measured at $100 \mathrm{kHz}$ with $\mathrm{HP} 4274 \mathrm{~A}$ from room temperature to $150^{\circ} \mathrm{C}$.

\section{Results and Discussion}

In fabrication of ferrite, many kinds of additives were used for the purpose of improving sinterbility, permeability, temperature stablity, frequency stability, low loss and so on.[5] In this experiment, we selected $\mathrm{Bi}_{2} \mathrm{O}_{3}$ which was wellknown as an accelarator of grain growth, and $\mathrm{Li}_{2} \mathrm{CO}_{3}$ was used for improving frequency stability of initial permeability. And the adding effect of $\mathrm{NiO}, \mathrm{Cr}_{2} \mathrm{O}_{3}$ was studied for the purpose of improving temperature stability of initial permeability.

Table.1 shows variations of properties with $\mathrm{NiO}$ concentration. With increasing $\mathrm{NiO}$ concentration, initial permeability, relative loss factor, saturation magnetization and relative temperature coefficient were decreased 
and Tc was increased. In general, initial permeability is explained with Globus's model $\mu_{i} \fallingdotseq \mathrm{Ms}^{2} \mathrm{D}_{m} / \mathrm{K}_{1}$ where $\mu_{1}$ is initial permeability, $M s$ is the saturation magneticzation, $D_{m}$ is the average grain diameter and $\mathrm{K}_{1}$ is the magnetocrystalline anisotropy. [6]

Table.1. Properties of the $\mathrm{NiO}$ added $\mathrm{Mg}-\mathrm{Cu}-\mathrm{Zn}$ ferrite.

\begin{tabular}{cccccc}
$\mathrm{NiO}(w \mathrm{t} \%)$ & $\mu \mathrm{i}$ & $\tan \delta / \mu \mathrm{i}\left(\mathrm{x} 10^{-5}\right)$ & $\mathrm{Tc}\left({ }^{\circ} \mathrm{C}\right)$ & $\mathrm{Ms}\left(\mathrm{mT}, 27^{\circ} \mathrm{C}\right)$ & $\alpha_{\mu \mathrm{r}}\left(\times 10^{-6} /{ }^{\circ} \mathrm{C}, 27 \sim 100^{\circ} \mathrm{C}\right)$ \\
\hline 0.0 & 567 & 9.47 & 129 & 270.0 & 15.48 \\
\hline 0.3 & 541 & 8.30 & 133 & 267.5 & 13.67 \\
0.6 & 518 & 8.23 & 134 & 265.4 & 13.36 \\
0.9 & 510 & 8.21 & 136 & 261.2 & 11.30 \\
1.2 & 478 & 7.82 & 146 & 260.8 & 10.26
\end{tabular}

Initial permeability was decreased with increase of concentration of $\mathrm{Ni}^{2+}$ ions which can be explained on the basis of Globus's model. Fig.1. shows microstructure variation according to the amount of $\mathrm{NiO}$ added.

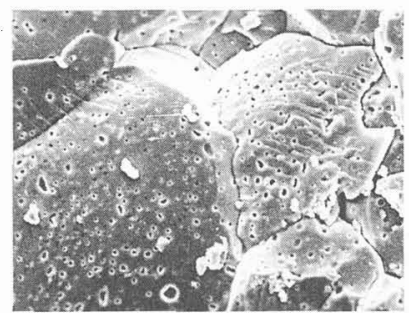

(a)

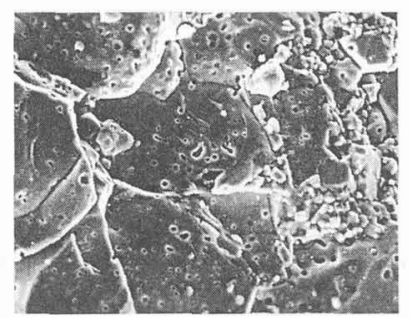

(b)

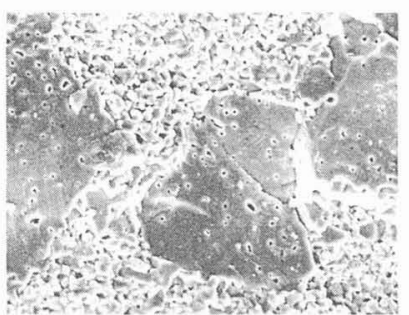

(c)

Fig.1 Microstructure of samples. (a) NiO 0.0wt\%, (b) NiO $0.6 \mathrm{wt} \%$, (c) $\mathrm{NiO} 12 \mathrm{wt} \%-20 \mathrm{~mm}$

With increasing $\mathrm{NiO}$ concentration, average grain size was decreased. However, abnormal grain growth occured in case of $1.2 \mathrm{wt} \%$ addition. The temperature dependence of initial permeability according to the $\mathrm{Ni}^{2+}$ concentration was illustrated in Fig.2. As seen, the curve shapes vary gradually with increasing $\mathrm{NiO}$ and the slope of the curve reduced with increasing $\mathrm{NiO}$. With increasing $\mathrm{NiO}$ concent, the relative temperature coefficient was decreased.

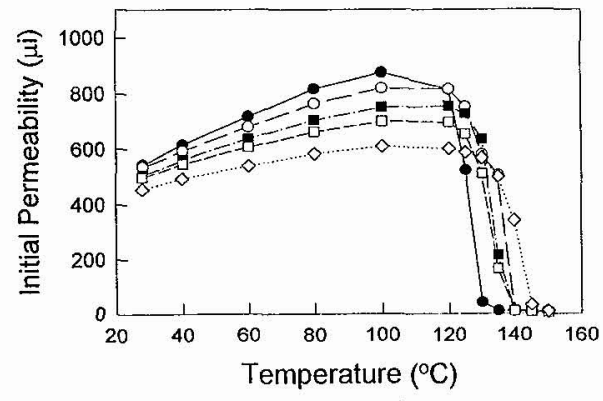

Fig.2. Temperature dependence of initial permeability.

The sample denoted by $\mathbf{Q}, 0, \mathbf{\square}, \square, \diamond$ is NiO content of $0.0,0.3,0.6,0.9,12$, respectively.
Table. 2 shows variation of properties with $\mathrm{Cr}_{2} \mathrm{O}_{3}$ concentration. With increasing $\mathrm{Cr}_{2} \mathrm{O}_{3}$ concentration, initial permeability was increased up to $0.6 \mathrm{wt} \%$ addition and then decreased over $0.6 \mathrm{wt} \%$ addition. Tc was decreased slightly according to the amount of $\mathrm{Cr}_{2} \mathrm{O}_{3}$ and relative temperature coefficient was decreased.

Table.2. Properties of the $\mathrm{Cr}_{2} \mathrm{O}_{3}$ added $\mathrm{Mg}-\mathrm{Cu}-\mathrm{Zn}$ ferrite.

\begin{tabular}{ccccc}
\hline $\mathrm{Cr}_{2} \mathrm{O}_{3}(\mathrm{wt} \%)$ & $\mu \mathrm{i}$ & $\tan \delta / \mu \mathrm{i}\left(10^{5}\right)$ & $\left.\mathrm{Td}^{\circ} \mathrm{C}\right)$ & $\alpha \mu \mathrm{r}\left(10^{6}\right)$ \\
\hline 0.0 & 567 & 9.47 & 129 & 15.48 \\
0.3 & 570 & 9.50 & 126 & 15.08 \\
0.6 & 580 & 9.54 & 124 & 7.47 \\
0.9 & 569 & 8.33 & 124 & 6.12 \\
1.2 & 516 & 8.01 & 120 & 5.55 \\
\hline
\end{tabular}

Temperature dependence of initial permeability is strongly affected by the variation of Ms and magnetocrystalline aniso-tropy $\left(K_{1}\right)$ as a function of temperature. Generally, Ms is decreased with increasing temperature because of the disordering of magnetic spin due to the effect of heat. But magnetocrystalline anisotropy is increased with temperature increasing, more rapidly than the decreasing of Ms. We assumed that $\mathrm{Ni}^{+2}, \mathrm{Cr}^{+3}$ ions entered crystal sites of $\mathrm{Mg}-\mathrm{Cu}-\mathrm{Zn}$ ferrite and varied magnetocrystalline anisotropy.

\section{Conclusion}

The introduction of the additives $\mathrm{NiO}, \mathrm{Cr}_{2} \mathrm{O}_{3}$ in $\mathrm{Mg}-\mathrm{Cu}-\mathrm{Zn}$ ferrite can successfully promote the temperature properties in lowering the relative temperature coefficient.

[1] K. Ohta, J. Phys. Soc., Japan, 18(1963) pp. 684.

\section{References}

[2] C. Guilland, P.I.E.E B suppl. 104(1957) pp. 165.

[3] Globus A. and Valenzuela R., IEEE Trans, Mag. 11 No.5,(1975) pp. 1300

[4] E Cedillo et al, J. Phys. E;Sci. Instrum.,Vol.13, (1980) pp. 383 386.

[5] 平賀貞太郎，フェライ\}，丸善株式會社,東京,(1986) pp. 9 76.

[6] Globus. A and Duplex. P, Physica Status Solid,(1969), pp. 31 